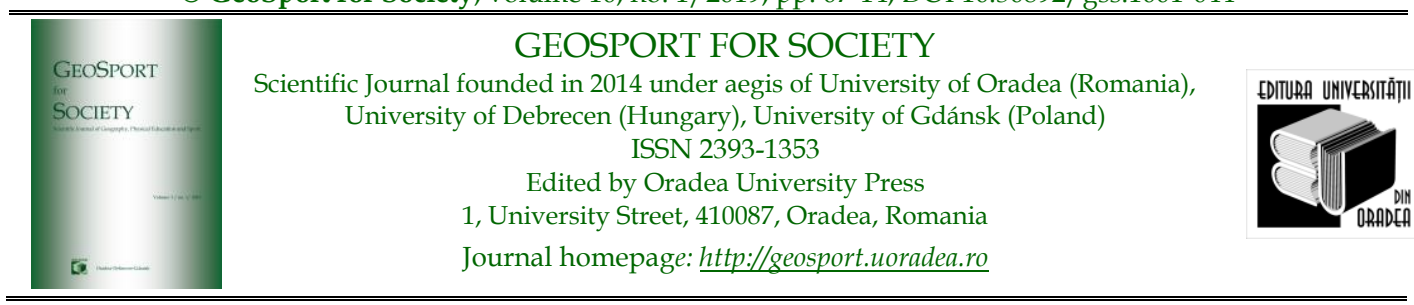

\title{
Comparative evolution of the phenomenon of geography of sports on national and global levels
}

\author{
Marin CHIRAZI * \\ 1. "Alexandru Ioan Cuza" University of Iasi, Faculty of Sports and Physical Education, str. Toma Cozma nr. 3. Iași, \\ Romania, e-mail: chirazim@yahoo.com \\ * Corresponding author \\ Citation: Chirazi M. (2019). Comparative evolution of the phenomenon of geography of sports on national and global \\ levels. Geosport for Society, 10(1), 7-14. https://doi.org/10.30892/gss.1001-044
}

Article history: Received: 07.10.2018; Revised: 20.11.2018; Accepted: 20.01.2019, Available online: 01.02.2019

\begin{abstract}
This study is a research of national and global evolution of literature on sports and geography with a view to emphasize emergence of a new category of study, least dealt with, whose impact on environment and society is tremendous. Sport is an inseparable component of society due to both its salubrious role through its effects and its necessary equipment and infrastructure. Sport activities are extremely diverse and most of the time they require special material conditions to practice it. This determines, while practice it, a relation of dependence to other fields as well: industrial, demographic, social, cultural, and political with local, national and global influences. Having in view optimisation of sport activities, from the perspective of inter-disciplinarity, a neighbouring field has been configured and developed and it has been called "geography of sports". Analysis of the specialised literature of the two fields (geography and sports) has led us to the conclusion that "geography of sports" has approached two main directions: geography of sports categories (it studies preference given to some sports in different areas), geography of sport infrastructure (it locates sport clubs, stadiums, sport facilities etc.) and geography of sport events (venues for organisation of sport events and their requirements). Also it has emphasised a series of studies on the influence of different geographic zones (mountains, seas, fields) on motor skills of the population, both from the point of view of preparation (athletic training) and from salubrious perspective.
\end{abstract}

Keywords: sports, geography, national, worldwide, comparison 


\section{Introduction}

Space analysis of the sport phenomenon in Romania has been and it is still superficially dealt with both from geographic and sport points of view. Thus, through this work we would like to emphasise the evolution of sport phenomenon while following a geographic approach with reference to the current situation of the society. Therefore, our intention is to present some methodological and conceptual approaches specific to geography since they are useful to spatial analysis of sports. At the same time these are being argued by emphasis laid on some interdisciplinary national and worldwide representative works which converge at Gaffney's statement according to whom "sport is inherently geographic” (Gaffney, 2014, p. 109).

The vast palette of the field "geography" has resulted in the emergence of a large number of sub-fields (Onose, 2009). Numerous professionals would argue that an excessive fragmentation of geography has been produced.

David Harvey stated that postmodernity characterises itself by a massive time space compression „in postmodernity, space and time have vanished, and this means they are lost a so are their meaning and control structure" (Barney, 2006, p. 22).

For an optimal development of sport activities, one can easily remark the importance of environmental components which represent the support of the two fields: geography and sport, and the complementarity connecting them, as well as their link to other fields.

Sport can be considered, due to qualitative and quantitative characteristics of its participants and viewers, as an indispensable activity to social life (Buhaș et al., $2018 \mathrm{a}, \mathrm{b})$. At the same time, the fact that sport is part of everyday life of the citizens on local, regional and global levels, requires a geographic analysis from the perspective of two essential elements: space and time. In specialised literature, one can find a serious number of interdisciplinary studies: geography and sports, tourism and sports, geography and sports medicine, ecology and sports, etc.

"Sports" phenomenon approaches aspects connected to opinions, benefits and behaviours of the population in its quality as a beneficiary (either practitioner or spectator) in relation to physical activity. Current dimensions of the phenomenon on the global level is due to media coverage: print media, radio and television, internet. Thus, sports can provide for a physical and psychic state of mind (no matter its role: either practitioner or spectator) while geography would provide for an optimal action space due to its landforms, weather conditions and economic level.

Sport as a physical activity, due to its forms of organisation and categories, owns a specific activity and it becomes an inseparable part to society. Sports activities are extremely varied and they are organically connected to the other fields such as: economic, demographic, social, cultural and politic environments, and can be reported to different levels, from the smallest space (localities with few inhabitants) to the regional, global and planetary levels.

Scientific feature required by preparation of the logistic support for sports activities (stadiums, mountain routes, waters, etc.) confers systematic functionality to its constituents. At the end they have an impact on society and they base themselves on different working methods and techniques specific to geography which within 
scientific context are being combined to those specific to sports, the most representative of them being the cartographic methods.

This study aims to follow the evolution of the relationship between sports and geography on the level of land planning and using or configuration of territorial system with a view to provide for a larger functionality for sports. On the scientific level, we identify a number of principles, methods and tools having been carefully selected to obtain the most convincing and useful results. Therefore, a series of representative scientific articles and materials will be presented to emphasise existence and importance of a systemic approach between sports and geography.

In the geographic analysis of sports, specific feature of geography is determined by two important elements: time and space. Space and time distribution of a phenomenon and configuration of a territorial pattern in compliance with characteristics of the element under analysis represents the result of a classical and entirely scientific geographic approach (Herman et al., 2016, 2018; Buhaș et al., 2017). Thus, a geographic analysis would better reflect the most representative, qualitative and quantitative aspects on the constituents of the system (Cocean, 2005).

\section{Content}

To define the area of Geography represents a different approach on its type and form and it will locally, regionally and globally generate the development of some activities due to which important benefits are to be obtained for society. Sport is defined by different ways and from different perspectives. In North America, terminology of sports is mostly associated to competitive game and it involves concepts indispensable to sport activity: time, space, specific rules (Mullin et al., 2014). Another definition relies on the fact that sport has another role as well, an uncompetitive role which is mostly based on maintaining wellness (fitness) and on recreation (Baidog and Herman, 2018; Fortin, 2000; Kogiso, 2015; Simson \& Jennings, 1992; Tătar et al., 2018). In international literature, relationship between geography and professional sports has been studied to a highly enough level.

Defined to a large scale, sports tourism represents the journey a person takes far from his dwelling place to participate to a sport activity for recreation or competition. Sport is well seen both as a recreational or competitive activity and a reason for travelling or visiting tourist attractions. Sports tourism represents an attractive and dynamic activity both on land (indoor or outdoor) and water environment (pools or open waters). Therefore, we could include in this category all participants to organised sport events. Sport events represent a tourist attraction to which spectators take part and they would generate several benefits in their turn since it requires a variety of services (Ilieş et al., 2014; Melo \& Sobry, 2017).

\section{Global Evolution and Development of the Area}

To better observe the evolution of the inter-disciplinarity relationship between the two fields: sports and geography, we would make reference to an article entitled "Sports and Geography: A Short Presentation" (Bale \& Dejonghe, 2008) published by 
the Belgeo magazine. This article presents studies written by representative authors within the area of sports geography.

Thus, the first studies to approach this area of geography and sports are considered to be information published by the French Elisée Reclus in 1879, who also presented some notions on the game of "Cricket" in World Geography. In 1919, Hilderbrand has "The Geography of Games" published in National Geographic and few years later, in 1927, the German geographer Hettner suggested that variations of health, hygiene, recreation and education, among other things, could be apprehended as a manifestation of nature of the land (Bale \& Dejonghe, 2008, 157-166). In the same editorial, one can find several themes involving the same areas: geography and sports, such as sports and migration, relationship between sports teams in the proper field and local identity in the neighbourhood, impact on sport events or stadiums on a certain zone, etc.

After Hettner has his work published in 1940, the Journal of Educational Research would publish the work Geographical Origin of Professional Baseball Players by Harvey Lehman who analysed differences among USA states in terms of training of the top baseball players. This work stands for fundamentals of any further attempt to approach sports from a geographic perspective.

At mid-fifties, Jokl and his colleagues from Finland (Sports in the Cultural Pattern of the World - 1956) presented the outcomes of a study "Geographical Variations in the National Composition of Participants in the 1952 Olympic Games". The theme of the study aimed at identifying regions where the members of the national team of Finland came from and provided for graphs and statistics of it while reflecting changes having occurred to geography, the so-called quantitative revolution in the fifties (Bale \& Dejonghe, 2008).

Another study was taken by Burley T.M. in 1966 and it was entitled "A Note on the Geography of Sport" and published in the "Professional Geographer". He showed that sport and geography have been tightly connected to other disciplines such as: economics, history and sociology and he stated that sports, more precisely mass sport (sports for all) has been a subject worthy of attention due to its economic importance, its social implications and its ability to indicate cultural origins and its contribution to the use of the urban land (Bale \& Dejonghe, 2008).

Modern sports "constitutes one of the numerous forms of culture which provides a vehicle for significant expression and communication" (Giossos, 2008, p. 53). Practice of sports plays a role of identity bearer while at the same time it contributes to the construction and reproduction of a significant part of individual's identity and not last of national identity.

Gábor Kozma (2014), in his work "The spatial development of sports facilities within the cities: a Central European case study", give special attention to spatial placement and development of sports facilities within localities.

\section{Current Stage of Geography of Sports on a National Level}

Characteristics of inter-disciplinarity is emphasised to be important and at the same time complex to approach it. Our study which deals with the theme of the geosport phenomenon is searching for useful conjuncture information to help us 
understand the situation. Thus, the political history has had an impact on sport activity. Since it has been ideologically framed, sports have been a propagandistic means of great importance while it has been used by the dictatorial regime in Romania.

Nevertheless, sport activity has made itself evident as an organised form by late $19^{\text {th }}$ century and early $20^{\text {th }}$ century. Specific feature of this period in sports is given by its selective characteristics and respectively by the possibility to practice sports which was granted only to a restricted group of wealthy people. Between the two wars, at the same time with the foundation of the National Institute for Sports and Physical Education in Bucharest, the first scientific studies would come into view. Thus, in 1938, an interdisciplinary theme was published in the Annals of Physical Education of the afore-mentioned institution Relation between Performance and Geographic Environment and signed by professors Iacob Mihăilă and Ulmeanu Florin Covaciu - Ulmeanu.

One of the first studies to draw a connection between the two areas is the article Contributions to cartographic representation of the sport phenomenon (Maroti \& Ilies, 1995) where the two authors achieve for the first time a map of distribution of practice of sport in our country. In the same direction, in 2005, it appears the article Possible Directions for Representation of Sport Phenomenon by Cartographic Means in Top Athletic Performance, between Utopia and Confirmation signed by Stasac et al.

Sandor I., in his doctoral thesis Rural Environment of Romania and its Possibilities to Athletic Performance, analyses and emphasises rural conditions of sportsmen to achieve athletic performances.

In his work Snow Cover in Support of Development of Winter Tourism Activities in Muntele Băișorii, the authors Gaceu et al. (2015) present the main characteristics of the snow cover in the resort Muntele Baisorii, and this allows, promotes and encourages the practice of tourism activities specific to winter season.

In his work Contributions of the Jewish Ethnics to the Development of Sports in the city of Cluj between the two Wars, Bogdan et al. $(2014,234)$, studies contribution of the Jewish community to the development of sports in the area of Cluj between the two Wars, while establishing some sport structures and managing it, and subsequently obtaining some results which belong nowadays to the athletic heritage of the city of Cluj.

In 2015, the authors Grama et al. (2015), in their work Evolution of the Olympic Basketball Tournaments from a Geographic Perspective present and analyse these tournaments while associating their results to the data studied by cartographic representation. In the first part of the work, the authors refer to a series of scientific articles which approach research as a result of the joint study of the professionals within the area of sports and physical education and geography.

Complex information of sports analysis has an interdisciplinary feature, contribute to the consolidation and completion of scientific contributions, development of some specific methods while adapting it to existing methods, but also to the expression of opinions by authors such as Iosif Sandor (2005), Vasile Bogdan (2016), Ionuț Onose (2016), who have their books published as a result of doctoral studies.

Sandor (2005) emphasizes both the possibilities of the rural population from the perspective of the somatic and physiological peculiarities having been formed by 
the specific of their daily routines, and disadvantages having been caused by poor economic situation.

The author Bogdan (2016), in his work Ambient Olympic Environment and Athletic Performance, gives emphasis to effects and economic and social importance of sports within the Olympic Games. Hence massive investments are being mentioned in relation to specific infrastructure required by competitions which will eventually remain for the use of the host locality. At the same time, it mentioned that all applicants to the Olympic Games have been the great economic powers of the world while the aspirers to front-ranks (general ranking) belong to the same countries.

In another part of the country, the region of Moldova, the work Incidence of Geo demographic structures on General Motor Skills of Elementary School Students appeared and it presented the outcomes of a thorough study on the influencing levels of motor skills of students who used to live in different geographic zones and altitudes (Onose, 2016).

\section{Debates}

In specialised literature, some authors would argue that in geographical studies, the space analysis of sports, the following principles have applicability: space analysis of distribution, causality, hierarchy, structuration, correlation, integration and chronology. At the same time, some methods and tools are mentioned and they would help the analysis of the phenomenon: observation, explanation, synthesis, description, comparison, modelling and not last the cartographic method - the most representative of it being achieved by GIS tools (Herman et al., 2016). Of course, part of the methods (observation, comparison, modelling) are to be encountered in sports research as well, but the fact that they are being used in geographical studies represents elements of inter-disciplinarity and facilitates apprehension of complexity of the interaction between the two scientific fields.

From the comparison of national and global ideas and types of approaches, some important causes have been identified and they eventually led to a low level of interest in geography of sports in our country:

- sport is a marginalised phenomenon within a society which is being torn by the social problems of that period;

- political transition and rearrangement of the industry to the coordinates of the market economy had led to diminished investment in sports and decreased political interest in most of sports (except for football), and depreciation of existing sports facilities;

- inexistence of some coherent directions and strategies for development of the tourism system with a view to encourage movement (mountain tourism, cycle tourism, aquatic tourism);

- habilitated institutions do not stimulate organisation and promotion of sports and physical education, and this is a field which is not currently managed by a national strategy;

- lack of some marketing strategies in relation to health tourism;

- lack of some operational strategies for landforms from the perspective of sport activities (watercourses, lakes, slopes, etc.); 
- encourage and promote sports specific to different geographical zone (water sports clubs around waters and routes for cycle tourism around cities, etc.).

\section{Conclusions}

The oldest approach to a sport from geographical perspective was made by the French Elisée Reclus in 1879 who presented several notions on the game of „cricket” in world geography.

In our country, the first renowned article dealing with an interdisciplinary theme was published in 1938, in the Annals of the National Academy of Sports and Physical Education of Bucharest (Relation between Performance and Geographical Environment).

Throughout the world, studies on the geography of sports are been divided into three categories:

- studies on preference to sports in certain geographical zones;

- approaches to geographical distribution of sports facilities and their impact on the environment;

- organisation of sports events on local, national and global levels and their implications.

In our country, interdisciplinary studies between sports and geography have the same main directions but another direction may be also noticed: effects of the specific feature of geographical zones (altitude, economic level, demographic level, specific cultures) on motor skills and somatic development of populations of different ages.

Similarly, one can say that development of the area of sports geography in Romania is the fruit of the collaboration between the two categories of higher education institutions where professionals from the two areas are being trained (Faculty of Geography and Faculty of Sports and Physical Education), especially in the area of Ardeal.

At the same time, the overall analysis of the bibliographical resources of the literature in our country has revealed that the area of sports geography makes her presence felt as a new interdisciplinary area while we are simultaneously attending an extension of studies throughout the entire territory of Romania.

As a general conclusion we could state that the study of sports from the perspective of the diverse geographical sub-domains/areas (economic geography, demographic geography, physical geography etc.) and geographical methods has led to numerous interdisciplinary studies and it determined emergence of the phenomenon "geo-sports" or ,geography of sports". In other words, the phenomenon of ",sports" can be also studied from the perspective of geography while the latter cannot be influenced but to a lesser extent and only occasionally by sports.

\section{References}

Baidog A., \& Herman, G.V. (2018). The Influence of Sports and Physical Activity on the Metabolic Syndrome: A Systematic Review. Analele Universităţii din Oradea Facicula Educaţie Fizică şi Sport, 28: 39-45.

Bale, J., \& Dejonghe, T. (2008). Sports Geography an Overview, Belgeo 2, 157-166.

Barney, W. (2006). Enciclopedia of Human Geography, Florida State University.

Bogdan, V. (2009). Mediul ambient olimpic şi performanţa sportivă, Editura GMI, București.

Bogdan, V., Maroti, S., \& Bocu, T. (2013). Contribuții ale etnicilor evrei la dezvoltarea sportului clujean în perioada interbelică. Palestrica of the Third Millennium Civilization \& Sport, 14(3): 234-238. 
Buhaș S., Herman G.V., Ștef M. (2018a), Aspects regarding the physical training level of "CSL Sporting Lugaș" female football team during the competitive year 2017-2018, Geosport for Society, 9(2): 63-70.

Buhaș S., Herman G.V., Ștef M. (2018b). Aspects regarding speed development in football game in 12 - 14 years old children. Geosport for Society, 8(1): 21-29.

Buhaș, D. S., Herman, G. V., Paul, F. D., \& Stance, L. (2017). Football and economy before and after communism in Romania. GeoSport for Society, 6(1): 30-39.

Cocean P. (2005). Geografie generală. Ediţia a II-a, revăzută şi adăugită, Editura Presa universitară Clujeană, Cluj-Napoca.

Fortin, F. (2000). Sport: The complet Visual Reference, Firefly Books, Richmond Hill.

Gaceu, O., Zarrilli, L., Gonzer, M., \& Pop, A. C. (2015). Snow cover in support of development of winter tourism activities in Muntele Băișorii resort. GeoSport for Society, 2(1), 7-20.

Gaffney, C. (2014). Geography of sport. Social Sciences in Sport (Gaffney eds.), Hardbak, 109-134.

Giossos, Y. P. (2008). Scoring for the homeland: The soccer team of the refugees of Volos. Studies in Physical Culture \& Tourism, 15(1): 53-63.

Grama, V., Manasses, I., \& Maroti, S., (2015). Evoluţia turneelor olimpice de baschet masculin din perspectivă geografică, Rev. Palestrica Mileniului III - Civilizaţie și Sport, 16 (2): 176-179.

Herman, G. V., Buhas, S. D., Stance, L., \& Pop, A. (2016). Considerations regarding the evolution, distribution and dynamics of the romanian football (League I) between 1989 - 2016. GeoSport for Society, 5(2): 69-78.

Herman, G. V., Ilieș, D. C., Baias, Ș., Măduța, M. F., Ilieș, A., Wendt, J., \& Josan, I. (2016), The tourist map, scientific tool that supports the exploration of protected areas, Bihor County, Romania, GeoSport for Society, 4(1), 24-32.

Herman, G. V., Szabo-Alexi, M., Szabo-Alexi, P., Dragoș, P. F., \& Marinău, M. (2018). The sport, vector of regionalization/globalization Case study: International Volleyball Federation (FIVB). GeoSport for Society, 8(1):40-50.

Ilieș, A., Dehoorne, O., Wendt, J., \& Kozma, G. (2014). For geography and sport, sport geography or geography of sport. GeoSport for Society, 1(1-2), 7-18.

Ilieș, D. C., Herman, G., Ilieș, A., Baias, S., Dehoorne, O., Buhaș, S., \& Ungureanu, M., (2017), Tourism and Biodiversity in Natura 2000 Sites. Case Study: Natura 2000 Valea Roșie (Red Valley) Site, Bihor County, Romania, Études caribéennes, (37-38).

Kogiso, K. (2015). The Success of Health Tourism in Thailand: A Big Demand for Asian Healing Arts. Sports Management and Sports Humanities (pp. 149-160). Springer, Tokyo.

Kozma, G. (2014). The spatial development of sports facilities within the cities: a Central European case study. Geosport for Society, 1(1-2), 19-28.

Lehman, H. C. (1940). The geographic origin of professional baseball players. The Journal of Educational Research, 34(2), 130-138.

Maroti, S., \& Ilieș, A. (1995), Contribuții la reprezentarea cartografică a fenomenului sportiv, în Resurse umane ale performanței sportive, Consiliul Științei Sportului din România, București.

Melo, R., \& Sobry, C. (Eds.). (2017). Sport Tourism: New Challenges in a Globalized World. Cambridge Scholars Publishing.

Mihăilă, J. (1938). Raportul dintre performanță şi mediul geografic. Analele de Educaţie Fizică, Academia Naţională de Educaţie Fizică, București.

Mullin, B. J., Hardy, S., \& Sutton, W. (2014). Sport Marketing 4th Edition. Human Kinetics.

Onose, I., (2016). Incidența structurilor geodemografice asupra capacităților motrice ale elevilor de gimnaziu, Editura Universității "Alexandru Ioan Cuza" din Iași.

Sandor, I. (2005). Mediul rural al României și posibilităţile acestuia pentru performanţa sportivă, Teză de doctorat, Universitatea Babeș-Bolyai, Cluj-Napoca.

Simson, V., \& Jennings, A. (1992). Dishonored games: Corruption, money \& greed at the Olympics. SP Books.

Stașac, M., Maroti, Ș., \& Ilieș, A., (2005). Direcții posibile de reprezentare a fenomenului sportiv prin mijloace cartografice in Performanța sportivă de vârf, între utopie și confirmări, Consiliul Știinţei Sportului din România, București.

Tătar, C. F., Herman, G. V., \& Pețan, P. (2018). Sport and physical activity engagement in Romania. Geosport for Society, 8(1), 40-50. 